\title{
LAND PRICE DYNAMICS IN A LARGE AUSTRALIAN URBAN HOUSING MARKET
}

Greg Costello, Curtin University, Perth, Western Australia

G.Costello@curtin.edu.au 


\section{Introduction}

Housing represents an important asset class which can be examined as composite goods in that the major components of price (value) comprise land and improvements (buildings) as relevant and varying proportions of total price over time. Hence, in theory the total value of any house, $V$ can be separated into the value of the land, $L$ and value of the (improvements), $B$ :

$$
V=L+B
$$

The empirical analysis of these components of house prices is prone to numerous difficulties addressed in detail in this paper. Whereas transaction prices for complete housing units $V$ might be readily available, accurate data for individual land $L$ and improvements $B$ components of housing attributes can be difficult to obtain. In addressing these issues and proposing the "land leverage hypothesis", (Bostic et al., 2007) developed a concise model for decomposing the influences of these components of total value. From equation (1), let $g_{L}, g_{B}$ and $g_{V}$ represent the periodic percentage change in the land, building and overall house values respectively, the value of a house at date $t+1$ can be expressed in two ways:

$$
V_{t+1}=V_{t}\left(1+g_{V}\right) \text { and } V_{t+1}=L_{t}\left(1+g_{L}\right)+B_{t}\left(1+g_{B}\right)
$$

By combining these two expressions and rearranging the terms, the overall rate of house price change can be decomposed as:

$$
g_{V}=g_{B}+\left(g_{L}-g_{B}\right) \lambda_{t}
$$

Where $\lambda_{t}=L_{t} / V_{t}$ and represents the individual land to total value ratio, or land leverage, as of date $t$. Equation (2) is only applicable in describing price dynamics if $g_{L}$ does not equal $g_{B}$, suggesting two paths by which price dynamics can differ over time, enabling more complexity in analysis both over time and across regions.

The interactions between land value, improvements and depreciation of structures have long been of interest in housing research and embrace numerous fields of established and evolving housing market theory. These include urban growth modeling, real option pricing and the evolving land leverage literature. To date, these new methods have only been applied in a small number of empirical studies, within specific (predominately US) housing markets. International housing markets are subject to distinctive institutional frameworks involving varying policy environments, capital constraints and market structures for exchange of housing assets. For these reasons it is important that new empirical method be applied to different international circumstances.

This paper applies method from the evolving land leverage literature within a large Australian housing market characterised by important distinctions from other international housing markets. In particular, Australian markets are differentiated by the large quantity of vacant residential land which after being initially sold, is often left undeveloped and later resold as vacant land. In contrast, most international housing markets consist of predominately improved sales whereby the newest stock 
of housing released to the market is in the form of completed housing estates. This characteristic of Australian housing markets is of particular importance in evaluating the real option influence in the pricing of land and improved property.

These distinctions between the components of property prices have also been of interest within the recent housing policy debate. In an Australian context, Richards (2008) suggests that the mid-2000's surge in house prices was "likely to mostly reflect an increase in the price of land" Richards (2008: p27). Similarly, Costello et al., (2011) raise the possibility of land leverage influences in explaining variations between house price movements in major Australian capital cities.

\section{(Figures $1 \& 2$ about here)}

Figures $1 \& 2$ provide some insights into these influences for a large aggregate housing market, the city of Perth, Western Australia 1989-2011. Figure 1 provides logarithmic price indexes constructed from annual median unit prices $(\$ / \mathrm{sqm})$ of market transactions for vacant land $(\mathrm{N}=195,840)$ and improved housing $(\mathrm{N}=$ $506,097)$. From Figure 1 it is evident that the unit price change for vacant land was higher than for improved housing over the sample period. The average annual unit price change for vacant land was approximately $8.9 \%$ whereas the corresponding change for improved housing was $7.7 \%$.

Figure 2, which displays annual unit price change confirms that this higher land growth rate was also accompanied by higher volatility. It is evident that in the majority of years the annual price change in the land series exceeded that of improved housing. The standard deviation of annual vacant land price changes was $10.9 \%$ whereas it was only $8 \%$ for improved housing. Interestingly, there are also a number of years during the sample period where there are contrasting annual price changes (positive $v$ negative). For example, in 1994 vacant land rates increased by more than $20 \%$ whereas improved housing recorded a slight negative decline. Although these results only reflect broad aggregate city-wide influences, the general pattern of these results are reflected in the more detailed and disaggregated empirical study to follow.

An improved knowledge of the influence of land leverage has important implications in understanding how housing markets operate. Most notably, land leverage can impact upon housing affordability, general land-use policy and the rational behaviour of property markets. The rest of this paper is organised as follows: section II extends on the motivation for this study and reviews significant related literature. Section III, describes methodology for decomposing house price components. Section IV, describes in detail the empirical study and results. Section V, concludes and provides recommendations for further research.

\section{Motivation and Related Literature}

The price of housing, volatility in housing markets and the important economic influence of housing wealth have become key issues for economic policymakers during the recent period of the Global Financial Crisis (GFC). The concept of land leverage has been demonstrated to have significant influence on price changes within housing markets and therefore significant influence upon house price volatility and affordability. 


\section{The Land - Improvements Distinction}

Economic theory suggests that price changes for land and improved property are likely to differ over time. Figure 1 provides evidence for both vacant land and improved properties in Perth. It is evident that price changes for vacant land were in excess of price changes for improved property during this period. Theory suggests the land and improvements components are unique as goods and their prices should respond differently to demand and supply stimuli. On the demand side, the improvements (structures) can be regarded as a capital input in housing production, whereas land capitalises the market value of location and urban infrastructure such as access to schools shopping and employment centres.

In terms of supply, improvements (structures) are reproducible and given access to materials and labour, easily reproduced. On the contrary, in most urban areas, desirable residential land is not easily reproduced, creating supply side asymmetry between the two components. Increases in demand for housing will therefore have different effects on the prices of the components. The cost pressures on building compete with other sectors of the economy and are determined by construction industry productivity. The construction industry competes with other industries for relevant labour and building resources, therefore changes in demand for housing are not as likely to impact on the price of structures. Alternatively, since land is largely non-reproducible, changes in demand for housing are likely to have a more significant influence on the price of land.

\section{Related literature}

Although empirical research into land leverage influences is only recent in the literature, the concepts of economic rent and by association land rent are a standard premise of early political economy and classical economic theory. Adam Smith (1776) first developed the theory of "rent of the land" to refer to a surplus in excess of other factors of production as a concept of land value or "land rent" as distinct from "contract rent". Following this earliest work, David Ricardo (1821) developed a general spatial model of land rent relating to intensity of land use (agricultural vs. urban land).

Following these early theoretical contributions, it was some time until suitable data became available to enable modern theoretical and empirical contributions from Hoyt (1933), and later Alonso (1964) Mills (1967; 1972) and Muth (1969), all of whom developed general urban form models relating commuting costs and distance from central urban places to explain spatial price trends in the price of land. From this work emerged the body of theory linking price gradients of land within urban areas to specific spatial influences, typically proximity to central points of cities or employment destinations (bid-rent relationships).

Extending on these contributions, Capozza and Helsley (1989) developed a theoretical model where the price of urban land is considered as having four additive components: agricultural land rent, cost of conversion (to urban land), expected future rent increases, and a growth premium. They argued that in rapidly growing cities the growth premium component comprises a major proportion of the average price of land and may create differentials between the price of land both within urban centres and on their peripheral boundaries. 
The primary empirical issue in studies of land leverage is accurate measurement of the ratio of land to total property value. This issue also defines the major differences for the principal empirical studies completed to this time. One group of studies, comprise macro analysis of major US housing markets (Case, 2007; Davis and Heathcote, 2007; Davis and Palumbo, 2008). In these studies, the primary methods have involved inferring general land values derived from time series data of housing and construction for major US cities.

Another group of studies (Bostic et al., 2007; Bourassa et al., 2009; 2011) have involved the analysis of micro data whereby the values of land and improvement components have been derived by either market transactions for vacant land and improved property, and/or assessors' estimates of land and/or improvement values corresponding with individual housing unit level transaction data.

Davis and Heathcote (2007) analysed a "benchmarked" US time series 1975-2006 comprising quarterly price indexes for residential land based on US Census and other data sources. They reported an approximate fourfold increase for the real price of US residential land over the sample period. After decomposing the series they reported that improvements increased by approximately one third, suggesting significant land leverage influences for the aggregate US housing market.

Davis and Palumbo (2008) used a different variation of the time-series technique to establish land values after depreciation of improvements for 46 large metropolitan areas in the US 1984-2004. In general, their results are consistent with the Davis and Heathcote (2007) study. They reported an overall land leverage ratio of $32 \%$ in 1984 increasing to $51 \%$ in 2004. An important feature of this study is the wide variation in land leverage ratios between cities suggesting that land leverage influences tended to be greater in more populated and more prosperous regions.

Case (2007) used similar data and methods to Davis and Heathcote (2007) to estimate land leverage ratios for residential property in the US 1975-2005, approximately $14 \%$ in 1975 increasing to $38 \%$ in 2005 . These estimates were substantially below those of Davis and Heathcote (2007) however some aspects of the results are similar to the Davis and Palumbo (2008) study. Whereas Case (2007) included some rural region data (farmhouses), this level of data was excluded from the other studies suggesting that these differences could be due to differences in sample selection procedures. A general conclusion which can be drawn from all of these macro US studies is that a distinct land leverage hierarchy exists in the US. The land leverage ratios in the largest cities grew at rates significantly above the aggregate market during all sample periods.

Bostic et al. (2007) demonstrated an empirical framework for analysis of land leverage influences with micro data, transactions of individual properties for Wichita, Kansas 1990-2004. They hypothesised that land leverage is positively correlated with house price change and provided convincing evidence to support the hypothesis. They used two distinct methodologies; a "market" approach and an "assessed value" approach. The market approach involved a smaller sample of new construction and followed the time path of transactions from vacant lot transactions through two subsequent improved transactions. The assessed value approach used local assessment records of land values to calculate individual land leverage ratios. These transactions were then analysed as repeat-sale pairs to estimate land 
leverage influences. This study demonstrated the applicability of a non-linear regression method to account for varying holding periods for individual repeat-sale transactions in addition to standard linear reduced form regressions to test for other influences on land leverage relationships. This methodology has been applied in the empirical study which follows.

Bourassa et al., (2009) hypothesised that houses appreciate at different rates depending on the characteristics of the property and the change in the strength of the overall housing market. They tested land leverage dynamics in New Zealand housing markets and reported greater price increases for properties with higher land leverage. They found that in their sample of three New Zealand cities, land leverage ratios were influential in explaining the pattern of price changes with respect to the aggregate housing market. They employed an assessed value approach using local assessment records and reported that higher land leverage was associated with higher volatility over the course of the property cycle.

Bourassa et al., (2011) employed a different approach for the analysis of land leverage influences in the Swiss housing market 1978-2008. They used individual transaction data but inferred land value estimates and land leverage ratios by using depreciated building costs to arrive at an improvements component of total value. From these micro data estimates, they developed hedonic models to estimate timeseries for land prices and land leverage ratios used in an error correction model to demonstrate the applicability of including land leverage variables with other housing fundamentals when assessing determinants of house price activity. Their results confirmed that land leverage was significantly affected by changes in real construction costs and in real GDP per capita.

Some recent related research suggests that land leverage relationships are inherent within the existing housing stock of large cities irrespective of the influence of new land supply due to the fact that many structures are long-lived and can be either redeveloped or ultimately demolished and re-built. This real option value to redevelop existing housing stock can play an important role in land leverage patterns within cities during different periods of the economic cycle (Clapp and Salavei 2010, Clapp et al., 2012).

\section{Methodology - Decomposing House Price Components}

The primary empirical issue in studies of land leverage is accurate measurement of the ratio of land to total property value. In studies involving the analysis of micro data whereby the values of land and improvement components have been derived by either market transactions and/or assessors' estimates, transactions can be decomposed through the simple model developed by Bostic et al., (2007) as outlined in the introductory discussion of equations (1) and (2) repeated below.

$$
\begin{aligned}
& V=L+B \\
& g_{V}=g_{B}+\left(g_{L}-g_{B}\right) \lambda_{t}
\end{aligned}
$$

An important implication of the land leverage hypothesis is that within a local market area, where land values are subject to the same economic fundamentals and influenced by the same aggregate rate of price change, each property's overall rate 
of price change should be positively related to its land leverage. To estimate this effect, it is necessary to specify:

$$
g_{V}=\beta_{0}+\beta_{1} \lambda_{t}+\varepsilon
$$

In estimation, the coefficients contain separate estimates of $g_{B}=\beta_{0}$ and $g_{L}=\beta_{1}+\beta_{0}$. The land leverage hypothesis implies $\beta_{1}>0$, which in turn implies $g_{L}>g_{B}$.

In equation (2), the land leverage identity is developed using periodic appreciation rates and the linear reduced form regression model in equation (3) assumes that $g_{V}$ can be observed for each individual property in each time period. Empirically, it is only possible to observe transaction prices at irregular intervals, and these intervals will differ for individual properties. To account for the reality of varying holding periods, it is necessary to compute total appreciation over each individual property's holding period.

Equation (2) can be rewritten as:

$$
g_{V}=\left(\left(1+g_{B}\right)^{T}+\left[\left(1+g_{L}\right)^{T}-\left(1+g_{B}\right)^{T}\right] \lambda_{t}\right)^{1 / T}-1
$$

Equation (4), accounts explicitly for varying holding periods for different properties. This functional form is nonlinear in the independent variables $T$ and $\lambda$. Equation (4) is estimated using nonlinear least squares to estimate population parameters $g_{B}$ and $g_{L}$. The empirical study which follows uses a rich data sample to estimate both the reduced form (equation 3 ) and structural versions (equation 4) of this model to test the implications of the land leverage hypothesis.

\section{The Empirical Study}

This study uses housing transaction data from the city of Perth, Western Australia. The data originate from an historical sales database administered by the Western Australian government 1995-2010. Perth is the capital and largest city in Western Australia and the fourth most populous city in Australia. In March 2011, the population was estimated at approximately 1.74 million persons (ABS: 2011).

\section{Sample selection}

To calculate land leverage for an individual property, the value of the land must be identified separately from the value of the improvements. This was achieved through an assessed value approach, where the land component of the land leverage ratio is derived from estimated land values at the year of sale. These estimates are taken from the procedures for providing unimproved land value assessments, a statutory requirement of the data provider. To be included in the sample an individual property must have sold at least two times, and only as an improved sale. A minimum oneyear holding period restriction was also imposed to guard against the influence of unobserved short-term capital expenditure and the fact that only single year (spot) estimates of land value are available for individual properties. 


\section{Construction of estimating variables}

For the sample, let $e L$ denote the yearly estimated land value for an individual transaction, $p 1$ and $p 2$ the prices of the first and second sales and $T$ the time between the sales in years. For each property, land leverage is calculated as $\lambda=e L / p 1$ and gross annual appreciation is calculated $g_{V}=(p 2 / p 1)^{1 / T}-1$

\section{Descriptive statistics}

Table 1 provides summary statistics. The sample provides 73,000 repeat-sale transactions with initial (first of pair) sales starting 1995:Q1 and subsequent sales extending through 2010:Q4. The average holding period (resale time) is 4.25 years; the average building age is 33 years with average lot size $758 \mathrm{sqm}$. With respect to the key empirical variables $g_{V}$ and $\lambda$; on average, individual properties in the sample increased at an annual rate of $12.33 \%$. With respect to land leverage $\lambda$, the average ratio for the sample is $63.11 \%$.

\section{(Table 1 about here)}

Table 2 and Figure 3 show the geographic distribution of data. In this case, the Perth Metropolitan area has been disaggregated according to specific sub-regions corresponding with the classification used by the Real Estate Institute of Western Australia (REIWA). Relevant statistics are shown in Table 2.

\section{(Table 2 and Figure 3 about here)}

By reference to land leverage statistics $\lambda$, the highest ratios occur in those subregions where the age of the housing stock is older. In general, these tend to be the central regions of the Perth Metropolitan area. Land leverage ratios are positively correlated with building age over the full sample (correlation 0.461). Average annual price changes, $g_{V}$ are also positively correlated with building age (correlation 0.126 ) although not as closely associated with the central sub-regions. Sub-regional variation in $g_{V}$ is supported by repeat sale indexes for houses (HPI) and vacant land (VLI) for 1995-2010. Annual property price changes, $g_{V}$ and the vacant land index (VLI) are strongly positively correlated across all sub-regions (0.413).

\section{Structural (non-linear) regression results}

Table 3 provides results from estimates of nonlinear structural models defined in equation (4). Results are shown for the full sample and sub-regions. The results confirm highly significant estimates for both land and building appreciation rates and provide strong evidence that land values account for the major proportion of overall house price appreciation in the full sample, and all sub-regions.

\section{(Table 3 about here)}

Results for the full sample indicate that building values grew at an average annual rate of $8.7 \%$ and land values grew at $13.9 \%$, consistent with the expectation of the land leverage hypothesis. Land component values in Perth have been growing at a faster rate than the improvement (building) component values. It is possible to verify the accuracy of these estimates through a diagnostic inherent within the estimation method. Equation 2 can be rewritten: 
$g_{V}=g_{B}(1-\lambda)+g_{L} \lambda$

Through this specification, the growth in overall property values can be decomposed as the weighted average of building and land growth rates, with weights based on land leverage. From coefficients in Table 3 and the full sample land leverage ratio of $63 \%$ (Table 2), the average full sample predicted growth rate is approximately $12 \%$ or $(0.12 \sim=0.087(1-0.63)+(0.139 \times 0.63)$. This estimate is close to the full sample mean growth rate of $12.3 \%$ (Table 2 ), an error of $\sim=0.004$. Results for this diagnostic are shown in the Error* column. For the full sample and the majority of sub-regions the results are robust in providing consistent estimates of land and building appreciation rates.

Significant variation exists across sub-regions with respect to growth in land and improvement components. Highest growth in land values is in the Wanneroo-South region $(18.9 \%)$, lowest in the Perth region (11.6\%), a range of $7.3 \%$. Highest rates of land appreciation are observed in outer sub-regions, areas associated with new housing and recent urban growth. Consistent with these results, the pattern is reversed when analysing building component growth. Highest growth in building is Perth $(11.8 \%)$, lowest Wanneroo-South $(5.0 \%)$ a range of $6.8 \%$. Highest growth in building values tends to be in older central regions, older building ages and higher proportions of "heritage" type housing stock.

\section{Reduced form regression results}

The advantages of the structural specification (equation 4) are that it accurately accounts for variation in holding period between properties in the sample and can be appropriately applied to the smaller sub-region samples. The disadvantages are that it is difficult to include and test other independent variables to check for stability of model specification. It is intuitive that other factors such as characteristics of individual houses, time of sale, location, may affect either land, $g_{L}$ unit price change or, $g_{B}$ and hence the overall appreciation rate $g_{V}$. Table 4 provides results from reduced form model specifications applied to the full sample using the general model specification discussed as equation (3)..

\section{(Table 4 about here)}

Model 1 is a simple linear regression of initial land leverage on annual growth, $g_{V}=\beta_{0}+\beta_{1} \lambda_{t}+\varepsilon$ (equation 3). Following earlier discussion, the constant term provides an estimate of, $g_{B}$ the building value growth. Land value growth, $g_{L}$ is calculated by summing the coefficient for $\lambda$ and the constant term. The estimates of $g_{B}=7.5 \%$ and $g_{L}=15 \%$ are roughly consistent with nonlinear estimates with land growth well in excess of building growth, supporting the influence of land leverage in overall house price growth.

Model 2 tests the influence of building age by including age at the subsequent sale, $p 2$ as an independent variable. Model 3 includes holding period in years between initial and subsequent sales as an additional independent variable. Note this specification does not confound holding period with building age since age at sale 1 + holding period in years would equal building age at sale 2 (age $p 1+\mathrm{HP}=$ age $p 2$ ). 
The influence of these variables is negligible with coefficients very close to zero, yet statistically significant at high levels and their inclusion in both models influence coefficients of the constant term and land leverage, $\lambda$.

Estimates for model 2 indicate that while building age is significant, it has no influence on the constant term but causes significant reduction in the influence of land leverage, approximately $2 \%$. In model 3 , where holding period is also included, both variables are highly significant and cause an increase in the constant term of approximately $1 \%$ and a further slight reduction in the influence of land leverage. In these models, building age and holding period variables are capturing some of the influence of building depreciation influences over time and hence influence the constant term, $g_{B}$.

The next set of models test for spatial variation in the influence of land leverage. Additional independent variables are introduced, sub-region dummy variables interacting with land leverage $\lambda$. Assuming that construction costs were generally equivalent across the city, location effects should only impact land price change $g_{L}$, not $g_{B}$.

Model 4, includes interaction terms with the Armadale / Serpentine sub-region the omitted category. From Table 2, this sub-region has the lowest land leverage ratio $(0.46)$ and is the omitted category. If the influence of land leverage is uniform across the Perth city region, the expectation is no significant difference for these interaction coefficients or some would be positive and significant relative to this sub-region as the omitted category.

Results for this regression provide evidence to support the proposition that land values have grown at different rates and the influence of land leverage varies spatially across the city according to sub-region. Many sub-region interaction coefficients are statistically significant with nine sub-regions displaying significant negative coefficients, against the expectation relative to the omitted category. A number of sub-regions have less significant positive coefficients consistent with expectation.

Estimated vacant land price indexes (Figure 1 \& Table 2) suggest likely variation in magnitude and temporal influence of land leverage dynamics. Expectation is that there are periods in the house price cycle when land leverage will vary in influence on overall price changes. To test this proposition, independent variables interacting land leverage with a dummy variable for year of sale are included in regressions.

Models 5 and 6 , estimate a set of models to test for interaction of temporal influences with land leverage. In these models dummy variables are specified according to the year of the second sale. Sample selection prohibits inclusion of sales of less than one year holding period therefore the omitted category is both years 1995-1996 from the full sample period 1995-2010.

A significant feature of these results is the impact on the overall land leverage variable $\lambda$, where the sign has changed to become negative and statistically significant at high levels providing strong evidence of temporal influence for land leverage dynamics over the full sample period. The analysis of individual time 
interaction coefficients confirms this influence.

The most significant influence occurs in the period 2003-2008 coinciding with significant house price increases across the city as indicated in Figure 1. Inclusion of time interaction variables does not significantly alter the general pattern of the subregion interaction variables, the majority maintaining similar coefficient sign and magnitude as before the inclusion of time interaction variables (model 4).

Model 6 also introduces variables to test the influence of physical characteristics entered into the model directly (not interaction terms). The size of lot area is insignificant and size of the building measured by total rooms (room count) is negative and statistically significant.

Model 6 also tests the influence of an "intensity" variable (land area / rooms) designed to test for the influence of site coverage. This result is weakly positive and statistically significant indicating higher rates of overall price change for properties more "intensely" developed.

Note also the significant change in the constant term, $g_{B}$ and the significant increase in explanatory power for the model arising from the inclusion of these time and construction variables. Remembering that the dependent variable in these regressions is the annual growth in property value, $g_{V}$ the coefficients are interpreted as the impact on growth rates rather than the direct impact of these characteristics on home values. Therefore, a negative coefficient on the size of the home (room count) implies that large homes have appreciated at a slower rate than smaller homes.

\section{Conclusion}

This study examines housing and land price dynamics for Perth, Australia 19952011. Results are consistent with some previous studies examining the "Land Leverage Hypothesis" in that the values of land and improvements on that land evolve differently over time. The land leverage influence is observed in different overall price changes in housing markets in response to similar macro-economic shocks which influence the price of land.

Consistent with similar studies, results confirm that price responses are positively related to the magnitude of land leverage. The study extends previous research through extensive spatial disaggregation of a larger more detailed data set than previously used in studies of this type confirming significant variation in land leverage ratios, overall price change and growth rates for land and improvements in subregional markets defined by spatial criteria.

The results have important implications concerning hedonic price analysis of housing markets. An important assumption of hedonic method is that estimates are considered accurate to the extent that all relevant features that contribute to value are identified. This study confirms that values of land and improvements typically do not change at the same rate. The omission of this influence from hedonic house price models is likely to lead to bias in measured prices. Land leverage provides a broad measure of value of all location amenities. The inclusion of this variable in hedonic regression could remove coefficient bias associated with omitted location 
amenity variables. This is an important issue that warrants further research.

The results also suggest an important role for policy development with respect to housing affordability and supply side regulation of land in large urban housing markets. While this study does not attempt to identify the key non-structural attributes of housing that account for variations in land values, the results clearly suggest important influences are at work at both aggregate and sub-regional levels. It is clear that "quality" or desirable land (location) is a prime driver of housing price change and subject to significant consumer discretion. In this environment, supplyside policy is important in providing a suitable flow of broad acre land and appropriate infrastructure in order for the addition of new housing stock which remains affordable and attractive to consumers of housing services.

Finally, these results have some important implications concerning the interaction between housing wealth and financial markets. Results suggest that house price movements are primarily driven by changes in the price of land, confirming that land price dynamics play an important role in connecting housing wealth to financial markets. In areas where homes are relatively expensive, higher land leverage ratios exist and in these areas house prices have appreciated more rapidly than on average. This suggests that as the land component of home value has increased over time, housing as an asset class may have become a more volatile financial asset due to the influences of increasing land leverage. 


\section{References}

ABS (2011), March 2011 Australian Bureau of Statistics Estimated Population http://www.abs.gov.au/AUSSTATS/subscriber.nsf/log?openagent\&32180ds0003 200110.xls\&3218.0\&Data\%20Cubes\&9F4C1AA38F0097DACA257863000E71FA\&0\&200910\&31

Alonso, W. (1964), Location and Land Use. Cambridge, MA: Harvard University Press.

Bostic, W., Longhofer, and S.D., Redfearn, C.L. (2007), 'Land Leverage: Decomposing Home Price Dynamics', Real Estate Economics, 35: 2: 183-208.

Bourassa, S.C., Haurin, DR, Haurin, J.L., Hoesli, M., Sun, J., (2009), 'House Price Changes and Idiosyncratic Risk: The Impact of Property Characteristics', Real Estate Economics, 37: 2: pp. 259-278.

Bourassa, S.C., Hoesli, M, Scognamiglio, D., Zhang, S., (2011), 'Land Leverage and House Prices', Regional Science and Urban Economics, 41:2: 134-144.

Capozza, D.R., Helsley, R.W. (1989), 'The Fundamentals of Land Prices and Urban Growth', Journal of Urban Economics, 26: 306.

Case, K., (2007), 'The Value of Land in the United States: 1975-2005', In: Ingram, G., Hong, Y.-H., (Eds), Land Policies and Their Outcomes. Lincoln Institute of Land Policy, Cambridge, MA

Clapp, J.M., Salavei, K., (2010), 'Hedonic Pricing with Redevelopment Options: a New Approach to Estimating Depreciation Effects', Journal of Urban Economics, 67: 362-377.

Clapp, J.M., Salavei Bardos, K., Wong, S.K. (2012), 'Empirical Estimation of the Option Premium for Residential Redevelopment', Regional Science and Urban Economics 42: 240256.

Costello, G., Fraser, P., Groenewold, N. (2011), 'House Prices, Non-fundamental Components and Interstate Spillovers: the Australian Experience', Journal of Banking and Finance, 35, 653-669.

Davis, M., Heathcote, J., (2007), 'The Price and Quantity of Residential Land in the United States', Journal of Monetary Economics, 54, 2595-2620.

Davis, M., Palumbo, M., (2008), 'The Price of Residential Land in Large US Cities', Journal of Urban Economics, 63, 352-384.

Hoyt, H., (1933), One Hundred Years of Land Values in Chicago: The Relationship of the Growth of Chicago to the Rise of Its Land Values, 1830-1933. The University of Chicago Press, Chicago.

Mills, E. (1967), 'An Aggregative Model of Resource Allocation in a Metropolitan Area', American Economic Review, 57:197-210.

Mills, E. (1972), Urban Economics, Glenview, IL: Scott Forseman.

Muth, R. (1969), Cities and Housing, Chicago: University of Chicago Press.

Ricardo, D. (1821), Principles of Political Economy and Taxation 3rd ed, London: John Murray.

Richards, A., (2008), 'Some Observations on the Cost of Housing in Australia', Address to 2008 Economic and Social Outlook Conference. Reserve Bank of Australia.

$<$ http://www.rba.gov.au/publications/bulletin/2008/apr/pdf/bu-0408-5.pdf>.

Smith, A. (1776), An Inquiry into the Nature and Causes of the Wealth of Nations, 5th edition, Edwin Cannan, ed, London: Methuen \& Co. Ltd. 1904. 


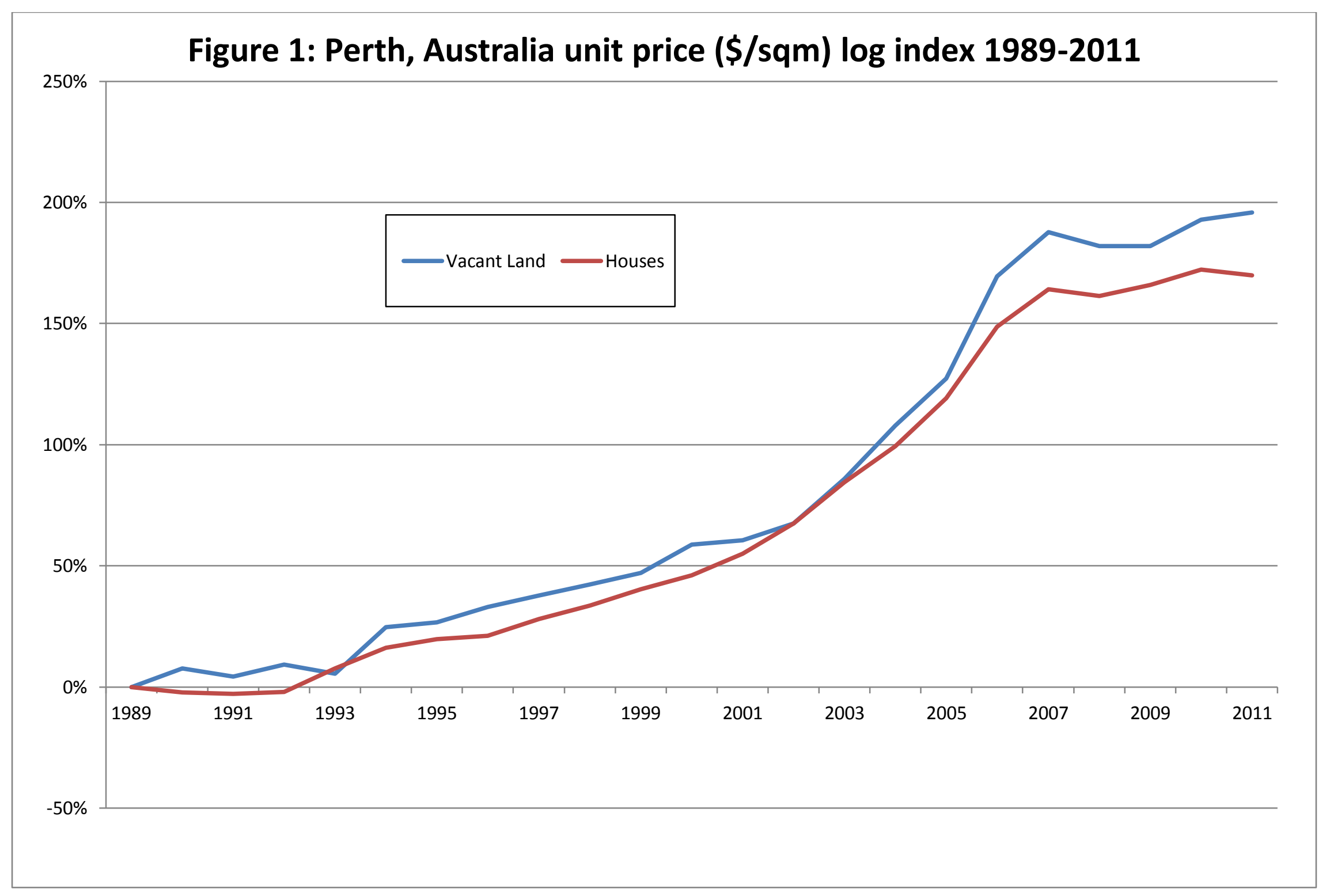




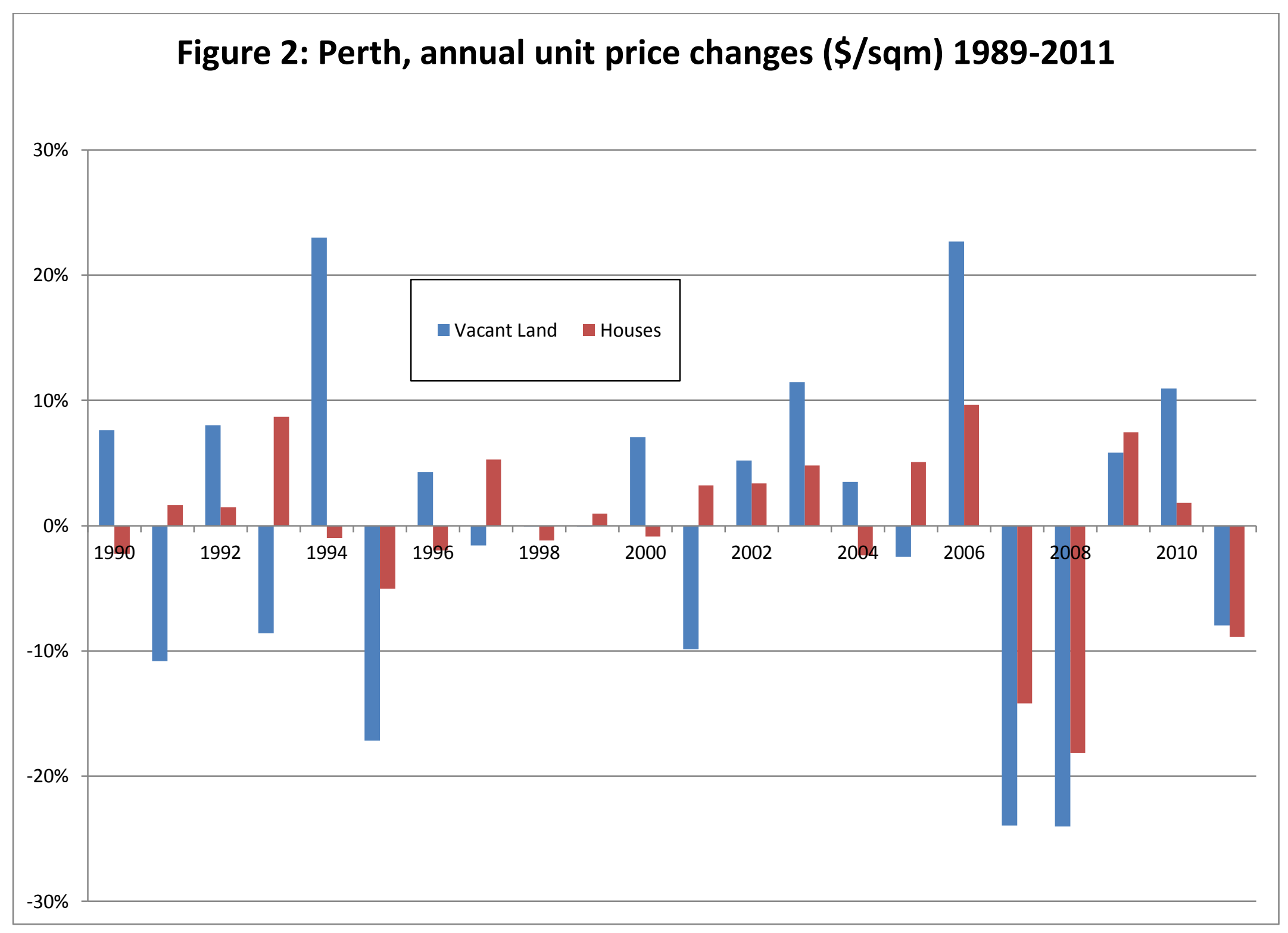


Table 1: Summary Statistics of the Sample

\begin{tabular}{|c|c|c|c|c|c|}
\hline \multicolumn{6}{|c|}{ Sample: 1995:Q1 - 2010:Q4 } \\
\hline Variable & Min. & Median & Max. & Mean & Std. Dev. \\
\hline Sale $_{1}$ & 1995:Q1 & 1999:Q4 & 2009:Q3 & 2000:Q2 & \\
\hline $\mathrm{Sale}_{2}$ & 1996:Q2 & 2004:Q2 & 2010:Q4 & 2004:Q3 & \\
\hline Resale time & 1.25 years & 3.75 years & 15.75 years & 4.25 years & 2.50 years \\
\hline Age at $\mathrm{Sale}_{2}$ & 1 year & 29 years & 133 years & 33 years & 18 years \\
\hline Bldg SQM ${ }^{\text {note } 1}$ & 33 & 183 & 1,001 & 194 & 78 \\
\hline Lot SQM & 118 & 728 & 2,255 & 758 & 199 \\
\hline Lot Price ${ }^{\text {note2 }}$ & $\$ 14,300$ & $\$ 100,100$ & $\$ 2,398,000$ & $\$ 143,291$ & $\$ 132,159$ \\
\hline Price $_{1}$ & $\$ 33,000$ & $\$ 162,000$ & $\$ 3,400,000$ & $\$ 217,025$ & $\$ 172,854$ \\
\hline Price $_{2}$ & $\$ 33,000$ & $\$ 288,000$ & $\$ 5,300,000$ & $\$ 360,289$ & $\$ 287,039$ \\
\hline$g_{V}$ & $-16.08 \%$ & $11.46 \%$ & $368.90 \%$ & $12.33 \%$ & $8.84 \%$ \\
\hline$\lambda$ note 3 & $7.53 \%$ & $61.50 \%$ & $110.00 \%$ & $63.11 \%$ & $16.20 \%$ \\
\hline$N$ & 73,000 & & & & \\
\hline \multicolumn{6}{|c|}{$\begin{array}{l}\text { Notes: } \\
\text { 1. Building area details are not available for all transactions, } 69,351 \text { observations have missing values. } \\
\text { 2. The lot price is derived from annual government assessors estimates of land value. } \\
\text { 3. The land leverage ratio is allowed to vary above } 100 \% \text { in the sample due to the fact that estimates occur at a single point } \\
\text { in a year. This allows for the fact that properties with estimated land values at the end of the year may be above actual land } \\
\text { values at the time of a transaction occurring at a beginning of the year. }\end{array}$} \\
\hline
\end{tabular}


Table 2: Geographic Distribution of the Sample

\begin{tabular}{|c|c|c|c|c|c|c|c|}
\hline \multirow[b]{2}{*}{ Sub-market region } & \multicolumn{5}{|c|}{ Sample: 1995:Q1 - 2010:Q4 } & \multicolumn{2}{|c|}{ Price Indexes * } \\
\hline & $N$ & $g_{V}$ & $\lambda$ & $\begin{array}{c}\text { Avg Sale } \\
\$, 000\end{array}$ & $\begin{array}{l}\text { Avg Age } \\
\text { Years }\end{array}$ & $\mathrm{HPI} \Delta$ & VLI $\Delta$ \\
\hline Full Sample & 73,000 & $12.3 \%$ & .63 & 288.7 & 32.6 & $9.8 \%$ & $9.9 \%$ \\
\hline Armadale / Serpentine & 3,739 & $11.2 \%$ & .46 & 160.2 & 26.8 & $9.2 \%$ & $9.1 \%$ \\
\hline Bassendean / Bayswater & 3,881 & $12.7 \%$ & .65 & 245.3 & 41.8 & $10.1 \%$ & $11.1 \%$ \\
\hline Belmont & 2,118 & $13.6 \%$ & .77 & 233.3 & 41.7 & $8.6 \%$ & $8.8 \%$ \\
\hline Canning & 4,879 & $12.1 \%$ & .69 & 261.0 & 30.4 & $10.1 \%$ & $9.7 \%$ \\
\hline Cockburn & 3,233 & $12.7 \%$ & .58 & 235.4 & 25.5 & $9.8 \%$ & $8.8 \%$ \\
\hline Fremantle & 1,365 & $13.1 \%$ & .71 & 434.4 & 57.0 & $8.4 \%$ & $8.9 \%$ \\
\hline Gosnells & 5,955 & $12.0 \%$ & .57 & 171.8 & 27.8 & $9.1 \%$ & $6.7 \%$ \\
\hline Hills & 3,767 & $12.2 \%$ & .56 & 219.7 & 27.0 & $9.4 \%$ & $9.9 \%$ \\
\hline Joondalup North & 2,635 & $11.8 \%$ & .55 & 266.1 & 18.1 & $10.2 \%$ & $10.3 \%$ \\
\hline Joondalup South & 8,905 & $12.2 \%$ & .61 & 286.9 & 24.7 & $10.9 \%$ & $10.6 \%$ \\
\hline Melville & 4,520 & $11.0 \%$ & .72 & 405.6 & 27.6 & $9.8 \%$ & $9.4 \%$ \\
\hline Perth & 152 & $11.3 \%$ & .72 & 426.9 & 77.9 & $5.3 \%$ & $4.7 \%$ \\
\hline Rockingham / Kwinana & 5,281 & $12.4 \%$ & .51 & 181.9 & 26.5 & $10.4 \%$ & $9.9 \%$ \\
\hline South Perth / Victoria Park & 2,285 & $12.1 \%$ & .78 & 403.7 & 52.9 & $10.5 \%$ & $9.6 \%$ \\
\hline Stirling East & 3,724 & $13.9 \%$ & .72 & 251.6 & 34.0 & $8.8 \%$ & $10.6 \%$ \\
\hline Stirling West & 2,631 & $13.1 \%$ & .79 & 429.2 & 38.9 & $10.6 \%$ & $10.3 \%$ \\
\hline Swan & 3,704 & $12.1 \%$ & .54 & 190.1 & 27.1 & $10.1 \%$ & $10.4 \%$ \\
\hline Vincent & 2,247 & $12.3 \%$ & .74 & 445.0 & 64.4 & $7.2 \%$ & $7.1 \%$ \\
\hline Wanneroo North East & 1,049 & $12.6 \%$ & .57 & 205.8 & 25.9 & $10.2 \%$ & $9.9 \%$ \\
\hline Wanneroo North West & 1,074 & $13.4 \%$ & .50 & 250.0 & 16.8 & $10.4 \%$ & $12.0 \%$ \\
\hline Wanneroo South & 1,545 & $12.9 \%$ & .53 & 176.9 & 22.2 & $10.8 \%$ & $10.0 \%$ \\
\hline Western Suburbs & 4,311 & $12.5 \%$ & .78 & 692.2 & 53.4 & $10.7 \%$ & $11.6 \%$ \\
\hline
\end{tabular}




\section{Figure 3: Perth Housing Submarkets}

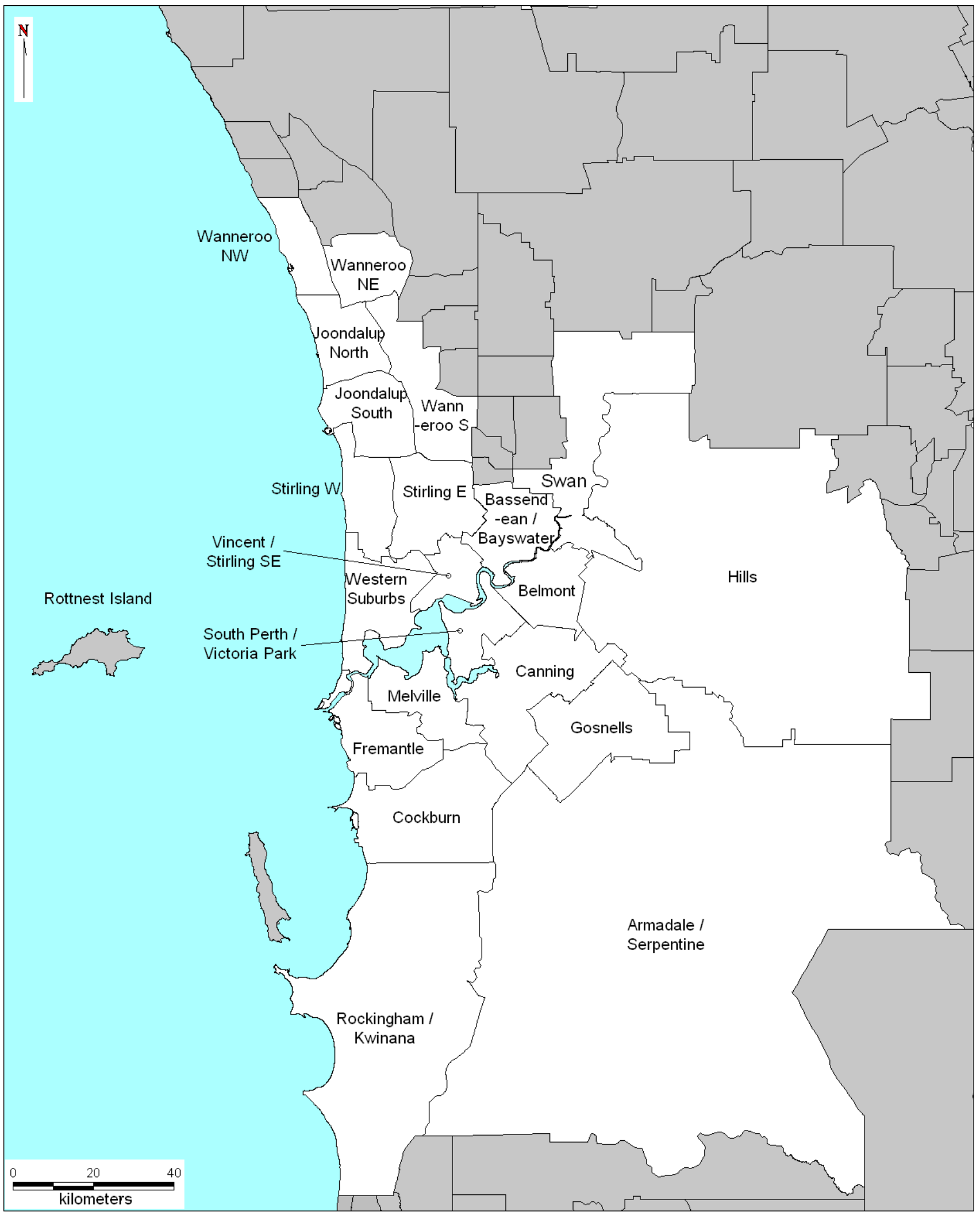


Table 3: Structural (Nonlinear) Regression Results

\begin{tabular}{|c|c|c|c|c|c|c|c|}
\hline Sub-region & $g_{L}$ & $t$ & $g_{B}$ & $t$ & Adj. $R^{2}$ & $N$ & Error * \\
\hline Full Sample & 0.139 & 411.9 & 0.087 & 99.9 & 0.607 & 73,000 & 0.004 \\
\hline Armadale / Serpentine & 0.161 & 59.6 & 0.062 & 11.9 & 0.472 & 3,739 & 0.005 \\
\hline Bassendean / Bayswater & 0.158 & 119.0 & 0.052 & 10.0 & 0.685 & 3,881 & 0.005 \\
\hline Belmont & 0.143 & 119.5 & 0.092 & 18.8 & 0.794 & 2,118 & 0.005 \\
\hline Canning & 0.131 & 101.6 & 0.088 & 22.2 & 0.645 & 4,879 & 0.003 \\
\hline Cockburn & 0.146 & 51.3 & 0.087 & 14.7 & 0.582 & 3,233 & 0.005 \\
\hline Fremantle & 0.138 & 78.1 & 0.104 & 18.4 & 0.730 & 1,365 & 0.003 \\
\hline Gosnells & 0.152 & 86.7 & 0.054 & 10.8 & 0.513 & 5,955 & 0.010 \\
\hline Hills & 0.146 & 63.1 & 0.075 & 14.6 & 0.550 & 3,767 & 0.007 \\
\hline Joondalup North & 0.159 & 63.9 & 0.059 & 9.9 & 0.625 & 2,635 & 0.004 \\
\hline Joondalup South & 0.148 & 140.7 & 0.072 & 25.3 & 0.700 & 8,905 & 0.003 \\
\hline Melville & 0.126 & 133.6 & 0.055 & 14.4 & 0.691 & 4,520 & 0.004 \\
\hline Perth & 0.116 & 19.1 & 0.118 & 8.2 & 0.729 & 152 & -0.004 \\
\hline Rockingham / Kwinana & 0.171 & 91.4 & 0.052 & 11.9 & 0.457 & 5,281 & 0.012 \\
\hline South Perth / Victoria Park & 0.127 & 98.0 & 0.103 & 21.0 & 0.705 & 2,285 & -0.000 \\
\hline Stirling East & 0.151 & 120.3 & 0.073 & 14.2 & 0.616 & 3,724 & 0.011 \\
\hline Stirling West & 0.146 & 149.1 & 0.085 & 18.3 & 0.789 & 2,631 & -0.002 \\
\hline Swan & 0.158 & 75.3 & 0.053 & 9.7 & 0.504 & 3,704 & 0.011 \\
\hline Vincent & 0.132 & 97.2 & 0.085 & 17.8 & 0.750 & 2,247 & 0.003 \\
\hline Wanneroo North East & 0.148 & 36.6 & 0.088 & 9.9 & 0.660 & 1,049 & 0.004 \\
\hline Wanneroo North West & 0.159 & 22.2 & 0.086 & 7.7 & 0.396 & 1,074 & 0.012 \\
\hline Wanneroo South & 0.189 & 50.8 & 0.050 & 5.4 & 0.528 & 1,545 & 0.004 \\
\hline Western Suburbs & 0.132 & 167.7 & 0.085 & 25.0 & 0.752 & 4,311 & 0.004 \\
\hline \multicolumn{8}{|c|}{$\begin{array}{l}\text { Note: the Error* is calculated by decomposing overall property price change as the weighted average } \\
\text { of the building and land growth rates, } g_{V}=g_{B}(1-\lambda)+g_{L} \lambda \text { with the weights based on land leverage } \\
\text { ratios in Table } 2 \text { and the regression coefficients in this table. As an example, for the full market sample, } \\
\text { the average predicted property value growth rate is } 9.04 \% \text { or }(0.094=0.075(1-0.3579)+(0.118 \times \\
0.3579) \text {. This estimate is close to the market sample mean growth rate of } 9.8 \% \text {, an error of } 0.008 \text {. }\end{array}$} \\
\hline
\end{tabular}


Table 4: Reduced Form Regression Results

\begin{tabular}{|c|c|c|c|c|c|c|}
\hline & Model 1 & Model 2 & Model 3 & Model 4 & Model 5 & Model 6 \\
\hline Constant $g B$ & $\begin{array}{c}0.077 \\
(59.15)^{\star *}\end{array}$ & $\begin{array}{c}0.077 \\
(59.32)^{\star *}\end{array}$ & $\begin{array}{c}0.087 \\
(62.59)^{\star *}\end{array}$ & $\begin{array}{c}.062 \\
(36.53)^{\star \star}\end{array}$ & $\begin{array}{c}.091 \\
(65.38)^{\star *}\end{array}$ & $\begin{array}{c}.126 \\
(39.72)^{\star *}\end{array}$ \\
\hline$\lambda(g L-g B)$ & $\begin{array}{c}0.073 \\
(36.60)^{* *}\end{array}$ & $\begin{array}{c}0.053 \\
(23.40)^{\star *}\end{array}$ & $\begin{array}{c}0.052 \\
(23.04)^{\star *}\end{array}$ & $\begin{array}{c}.086 \\
(19.09)^{\star *}\end{array}$ & $\begin{array}{c}-.091 \\
(12.05)^{\star *}\end{array}$ & $\begin{array}{c}-.118 \\
(15.52)^{\star *}\end{array}$ \\
\hline Age at second sale & & $\begin{array}{l}4.0 \mathrm{E}-04 \\
(19.88)^{\star *}\end{array}$ & $\begin{array}{l}4.0 \mathrm{E}-04 \\
(21.78)^{\star *}\end{array}$ & $\begin{array}{c}.001 \\
(31.05)^{\star *}\end{array}$ & $\begin{array}{l}4.7 \mathrm{E}-04 \\
(25.10)^{\star *}\end{array}$ & $\begin{array}{l}2.2 \mathrm{E}-04 \\
(9.96)^{* *}\end{array}$ \\
\hline Holding period (years) & & & $\begin{array}{c}-0.003 \\
(19.83)^{\star *}\end{array}$ & $\begin{array}{c}-.003 \\
(19.57)^{\star *}\end{array}$ & $\begin{array}{c}-.006 \\
(54.58)^{\star *}\end{array}$ & $\begin{array}{c}-.006 \\
(55.39)^{\star *}\end{array}$ \\
\hline Bassendean / Bayswater $\mathrm{x} \lambda$ & & & & $\begin{array}{c}-.016 \\
(4.19)^{\star \star}\end{array}$ & $\begin{array}{c}-.006 \\
(1.91)\end{array}$ & $\begin{array}{c}.004 \\
(1.18)\end{array}$ \\
\hline Belmont $x \lambda$ & & & & $\begin{array}{c}-.014 \\
(3.43)^{\star *}\end{array}$ & $\begin{array}{c}-.012 \\
(3.84)^{\star *}\end{array}$ & $\begin{array}{l}-.005 \\
(1.44)\end{array}$ \\
\hline Canning $\times \lambda$ & & & & $\begin{array}{c}-.017 \\
(4.55)^{\star *}\end{array}$ & $\begin{array}{c}-.013 \\
(4.60)^{\star *}\end{array}$ & $\begin{array}{l}-.001 \\
(0.47)\end{array}$ \\
\hline Cockburn $\times \lambda$ & & & & $\begin{array}{c}.015 \\
(3.73)^{\star *}\end{array}$ & $\begin{array}{c}.007 \\
(2.21)^{*}\end{array}$ & $\begin{array}{c}.014 \\
(4.39)^{* *}\end{array}$ \\
\hline Fremantle $\mathrm{x} \lambda$ & & & & $\begin{array}{c}-.029 \\
(6.24)^{\star *}\end{array}$ & $\begin{array}{c}-.018 \\
(5.00)^{\star *}\end{array}$ & $\begin{array}{l}-.003 \\
(0.76)\end{array}$ \\
\hline Gosnells $\times \lambda$ & & & & $\begin{array}{c}.000 \\
(0.05)\end{array}$ & $\begin{array}{l}-.002 \\
(0.55)\end{array}$ & $\begin{array}{c}.005 \\
(1.76)\end{array}$ \\
\hline Hills $x \lambda$ & & & & $\begin{array}{c}.008 \\
(2.02)^{*}\end{array}$ & $\begin{array}{l}-.002 \\
(0.71)\end{array}$ & $\begin{array}{c}.004 \\
(1.19)\end{array}$ \\
\hline Joondalup North $\mathrm{x} \lambda$ & & & & $\begin{array}{c}.012 \\
(2.86)^{*}\end{array}$ & $\begin{array}{c}.006 \\
(1.73)\end{array}$ & $\begin{array}{c}.019 \\
(5.37)^{\star *}\end{array}$ \\
\hline
\end{tabular}


Table 4: Reduced Form Regression Results (cont'd)

\begin{tabular}{|c|c|c|c|c|c|c|}
\hline & Model 1 & Model 2 & Model 3 & Model 4 & Model 5 & Model 6 \\
\hline Joondalup South $\mathrm{x} \lambda$ & & & & $\begin{array}{c}.002 \\
(0.47)\end{array}$ & $\begin{array}{l}-.001 \\
(0.24)\end{array}$ & $\begin{array}{c}.013 \\
(4.65)^{\star *}\end{array}$ \\
\hline Melville $x \lambda$ & & & & $\begin{array}{c}-.030 \\
(8.16)^{\star \star}\end{array}$ & $\begin{array}{c}-.027 \\
(9.42)^{\star *}\end{array}$ & $\begin{array}{c}-.011 \\
(3.62)^{\star *}\end{array}$ \\
\hline Perth $\times \lambda$ & & & & $\begin{array}{c}-.078 \\
(7.66)^{* *}\end{array}$ & $\begin{array}{c}-.049 \\
(6.13)^{\star *}\end{array}$ & $\begin{array}{c}-.029 \\
(3.60)^{* *}\end{array}$ \\
\hline Rockingham / Kwinana $\times \lambda$ & & & & $\begin{array}{c}.019 \\
(5.09)^{\star *}\end{array}$ & $\begin{array}{c}.016 \\
(5.29)^{\star *}\end{array}$ & $\begin{array}{c}.021 \\
(6.87)^{\star *}\end{array}$ \\
\hline South Perth / Victoria Park $\mathrm{x} \lambda$ & & & & $\begin{array}{c}-.046 \\
(11.59)^{* *}\end{array}$ & $\begin{array}{c}-.032 \\
(9.96)^{\star *}\end{array}$ & $\begin{array}{c}-.017 \\
(5.27)^{* *}\end{array}$ \\
\hline Stirling East $\mathrm{x} \lambda$ & & & & $\begin{array}{c}.000 \\
(0.10)\end{array}$ & $\begin{array}{c}.004 \\
(1.35)\end{array}$ & $\begin{array}{c}.013 \\
(4.26)^{\star *}\end{array}$ \\
\hline Stirling West $\mathrm{x} \lambda$ & & & & $\begin{array}{c}-.020 \\
(5.11)^{\star *}\end{array}$ & $\begin{array}{c}-.009 \\
(2.97)^{*}\end{array}$ & $\begin{array}{c}.004 \\
(1.39)\end{array}$ \\
\hline Swan $\times \lambda$ & & & & $\begin{array}{c}.003 \\
(0.79)\end{array}$ & $\begin{array}{c}.004 \\
(1.20)\end{array}$ & $\begin{array}{c}.011 \\
(3.38)^{* *}\end{array}$ \\
\hline Vincent $\mathrm{x} \lambda$ & & & & $\begin{array}{c}-.050 \\
(12.05)^{\star \star}\end{array}$ & $\begin{array}{c}-.031 \\
(9.28)^{\star *}\end{array}$ & $\begin{array}{c}-.013 \\
(3.69)^{\star *}\end{array}$ \\
\hline Wanneroo North East $\mathrm{x} \lambda$ & & & & $\begin{array}{c}.012 \\
(2.25)^{*}\end{array}$ & $\begin{array}{c}.004 \\
(0.83)\end{array}$ & $\begin{array}{c}.011 \\
(2.43)^{\star}\end{array}$ \\
\hline Wanneroo North West $x \lambda$ & & & & $\begin{array}{c}.050 \\
(8.43)^{\star *}\end{array}$ & $\begin{array}{c}.029 \\
(6.08)\end{array}$ & $\begin{array}{c}.035 \\
(7.41)^{\star \star}\end{array}$ \\
\hline Wanneroo South $\mathrm{x} \lambda$ & & & & $\begin{array}{c}.029 \\
(5.80)^{\star *}\end{array}$ & $\begin{array}{c}.023 \\
(5.69)^{\star *}\end{array}$ & $\begin{array}{c}.026 \\
(6.52)^{* *}\end{array}$ \\
\hline
\end{tabular}


Table 4: Reduced Form Regression Results (cont'd)

\begin{tabular}{|c|c|c|c|c|c|c|}
\hline & Model 1 & Model 2 & Model 3 & Model 4 & Model 5 & Model 6 \\
\hline Western Suburbs $\mathrm{x} \lambda$ & & & & $\begin{array}{c}-.040 \\
(10.98)^{\star \star}\end{array}$ & $\begin{array}{c}-.027 \\
(9.31)^{\star *}\end{array}$ & $\begin{array}{c}-.009 \\
(2.79)^{\star *}\end{array}$ \\
\hline $1997 \times \lambda$ & & & & & $\begin{array}{c}.020 \\
(2.69)^{*}\end{array}$ & $\begin{array}{c}.019 \\
(2.60)^{\star}\end{array}$ \\
\hline $1998 \times \lambda$ & & & & & $\begin{array}{c}.051 \\
(7.39)^{\star *}\end{array}$ & $\begin{array}{c}.051 \\
(7.40)^{\star *}\end{array}$ \\
\hline $1999 \times \lambda$ & & & & & $\begin{array}{c}.077 \\
(11.29)^{\star *}\end{array}$ & $\begin{array}{c}.077 \\
(11.40)^{\star *}\end{array}$ \\
\hline $2000 \times \lambda$ & & & & & $\begin{array}{c}.084 \\
(12.37)^{\star \star}\end{array}$ & $\begin{array}{c}.085 \\
(12.58)^{\star *}\end{array}$ \\
\hline $2001 \times \lambda$ & & & & & $\begin{array}{c}.082 \\
(12.20)^{\star *}\end{array}$ & $\begin{array}{c}.083 \\
(12.46)^{\star *}\end{array}$ \\
\hline $2002 \times \lambda$ & & & & & $\begin{array}{c}.117 \\
(17.46)^{\star \star}\end{array}$ & $\begin{array}{c}.119 \\
(17.83)^{\star *}\end{array}$ \\
\hline $2003 \times \lambda$ & & & & & $\begin{array}{c}.177 \\
(26.42)^{\star \star}\end{array}$ & $\begin{array}{c}.180 \\
(26.90)^{\star *}\end{array}$ \\
\hline $2004 \times \lambda$ & & & & & $\begin{array}{c}.198 \\
(29.59)^{\star \star}\end{array}$ & $\begin{array}{c}.201 \\
(30.13)^{\star *}\end{array}$ \\
\hline $2005 \times \lambda$ & & & & & $\begin{array}{c}.223 \\
(33.35)^{\star \star}\end{array}$ & $\begin{array}{c}.227 \\
(34.04)^{\star *}\end{array}$ \\
\hline $2006 \times \lambda$ & & & & & $\begin{array}{c}.344 \\
(51.11)^{\star \star}\end{array}$ & $\begin{array}{c}.349 \\
(51.92)^{\star *}\end{array}$ \\
\hline
\end{tabular}


Table 4: Reduced Form Regression Results (cont'd)

\begin{tabular}{|c|c|c|c|c|c|c|}
\hline & Model 1 & Model 2 & Model 3 & Model 4 & Model 5 & Model 6 \\
\hline $2007 \times \lambda$ & & & & & $\begin{array}{c}.284 \\
(42.05)^{\star *}\end{array}$ & $\begin{array}{c}.289 \\
(43.00)^{\star *}\end{array}$ \\
\hline $2008 \times \lambda$ & & & & & $\begin{array}{c}.176 \\
(25.95)^{\star *}\end{array}$ & $\begin{array}{c}.183 \\
(26.99)^{\star *}\end{array}$ \\
\hline $2009 \times \lambda$ & & & & & $\begin{array}{c}.124 \\
(18.35)^{\star *}\end{array}$ & $\begin{array}{c}.131 \\
(19.41)^{\star *}\end{array}$ \\
\hline $2010 \times \lambda$ & & & & & $\begin{array}{c}.116 \\
(17.17)^{\star *}\end{array}$ & $\begin{array}{c}.124 \\
(18.33)^{\star *}\end{array}$ \\
\hline Land Area & & & & & & $\begin{array}{c}.000 \\
(0.66)\end{array}$ \\
\hline Room Count & & & & & & $\begin{array}{c}-.003 \\
(8.78)^{* *}\end{array}$ \\
\hline Intensity (Land Area/Rooms) & & & & & & $\begin{array}{c}.0001 \\
(2.42)^{*}\end{array}$ \\
\hline Observations & 73,000 & 73,000 & 73,000 & 73,000 & 73,000 & 73,000 \\
\hline Adj. R-squared & 0.018 & 0.023 & 0.029 & 0.045 & 0.397 & 0.400 \\
\hline
\end{tabular}

